\title{
Role of the nervous system in cancer metastasis
}

Nyanbol Kuol ${ }^{1}$, Lily Stojanovska', Vasso Apostolopoulos ${ }^{1+}$ and Kulmira Nurgali ${ }^{1,2^{* \dagger}}$ (D)

\begin{abstract}
Cancer remains as one of the leading cause of death worldwide. The development of cancer involves an intricate process, wherein many identified and unidentified factors play a role. Although most studies have focused on the genetic abnormalities which initiate and promote cancer, there is overwhelming evidence that tumors interact within their environment by direct cell-to-cell contact and with signaling molecules, suggesting that cancer cells can influence their microenvironment and bidirectionally communicate with other systems. However, only in recent years the role of the nervous system has been recognized as a major contributor to cancer development and metastasis. The nervous system governs functional activities of many organs, and, as tumors are not independent organs within an organism, this system is integrally involved in tumor growth and progression.
\end{abstract}

Keywords: Neurotransmitters, Neuropeptides, Neuro-cancer interaction, Metastasis, Cancer

\section{Background}

Cancer is the leading cause of death worldwide due to the aging population and unhealthy lifestyle [1]. Although it is highly treatable when localized, metastatic or recurrent cancer has a poor prognosis. Metastasis involves a complex series of steps including proliferation, angiogenesis, embolization, dissemination, evasion of immune system surveillance and surviving in ectopic organs [2-5]. However, despite significant advances in understanding metastasis and its mechanisms, the prognosis remains poor. In the past decades, research has focused on identifying and characterising genes and gene products that manipulate the metastatic processes [6-9]. More recently, the impact of the tumor microenvironment on tumor cell invasion and metastasis has attracted extensive attention (see ref. [10] for detailed review) [2, 10-13]. Multiple cellular and extracellular components within the tumor microenvironment, such as immune cells, endothelial cells, mesenchymal stromal cells (fibroblasts and myofibroblasts), and their secretory products, exert active functions to modulate gene expression patterns of tumor cells and to alter biological behavior

\footnotetext{
* Correspondence: Kulmira.Nurgali@vu.edu.au

${ }^{\dagger}$ Equal contributors

${ }^{1}$ Centre for Chronic Disease, College of Health and Biomedicine, Victoria University, Melbourne, Australia

${ }^{2}$ Department of Medicine, Western Health, The University of Melbourne,

Regenerative Medicine and Stem Cells Program, AIMSS, Melbourne, Australia
}

of tumor cells [14-16]. Invariable crosstalk amongst these components within the tumor microenvironment triggers pro-survival, invasion, and metastatic pathways of tumor cells [17-20]. Several studies, both clinical and in vitro, reinforce the concept of the nervous system involvement in cancer metastasis [5, 21-26]. Nerve fibers present in and around the tumor could release neurotransmitters and neuropeptides directly acting on receptors expressed by cancer cells. The findings, primarily in cancer cell lines and animal models, indicate that there is a bi-directional correlation between the neural factors released and cancer progression and metastasis. Understanding the complex neurotransmitter-cancer interaction is important for the development of new avenues for targeted therapeutic intervention. This review presents an overview of the role of the nervous system in cancer metastasis.

\section{The role of the nervous system in metastatic cascade}

Studies have demonstrated that the nervous system facilitates development of tumor metastasis by modulating metastatic cascades through the release of neural-related factors from nerve endings such as neurotrophins, neurotransmitters and neuropeptides [27-29]. The process of metastasis formation involves tumor cells breaking away from the primary tumor and overcoming the 
obstacles of primary tissue inhibition (initiation and clonal expansion), anoikis inhibition (evasion from apoptosis), breakdown of base membranes (epithelial-mesenchymal transition (EMT) and invasion), extravasation and colonization, angiogenesis, evasion of immune response and establishment of tumor microenvironment.

\section{Initiation and clonal expansion}

Tumor metastasis initiation and clonal expansion is a complex process where contributing factors are not well understood. It is believed that metastasis process is initiated when genetically unstable tumor cells adjust to a secondary site microenvironment [11]. This process involves selecting traits that are beneficial to tumor cells and affiliated recruitment of traits in the tumor stroma that accommodate invasion by metastatic cells. Metastasis-initiating cells possess these traits and can hijack some of the normal stem cell pathways to increase cellular plasticity and stemness [30]. Proteolytic enzymes such as matrix metalloproteinases (MMPs) facilitate this process by degrading the surrounding normal tissues. MMPs are regulated by neural-related factors and neurotransmitters and are overexpressed in tumors [31-35]. Hence, nervous system modulates the initiation and clonal expansion via the expression of MMPs and the stimulation of metastasis-initiating cells.

\section{Evasion from apoptosis}

Anoikis is a programmed cell death induced upon cell detachment from extracellular matrix, acting as a critical mechanism in preventing adherent-independent cell growth and attachment to unsuitable matrix, thus avoiding colonizing of distant organs [36, 37]. For tumor metastasis to progress, tumor cells must be resistant to anoikis. Tumor cell resistance to anoikis is attributed to alteration in integrins' repertoire, overexpression of growth factor receptor, activation of oncogene, activation of pro-survival signals, or upregulation/mutation of key enzymes involved in integrin or growth factor receptor signaling [37]. Neurotransmitters and neurotrophins play a role in tumor evasion from anoikis. Increased expression of brain-derived neurotrophic factor (BDNF) and its receptor tropomyosin-related kinase B (TrkB) induces anoikis inhibition in rat intestinal epithelial cells [27]. Similarly, TrkB overexpression induces anoikis inhibition protecting colorectal cancer cells [38]. Application of recombinant human BDNF to gastric cancer cells inhibited anoikis and stimulated cellular proliferation, invasion and migration [39]. Nicotine exposure promotes anchorageindependent growth of A549, MDA-MB-468 and MCF-7 cell lines by downregulation of anoikis [40]. Furthermore, tumor microenvironment contributes to anoikis resistance of cancer cells by producing pro-survival soluble factors, triggering EMT, enhancing oxidative stress, regulating matrix stiffness, as well as leading to metabolic deregulations of cancer cells [37]. These events assist tumor cells to prevent the apoptosis mechanism and sustain prosurvival signals after detachment, counteracting anoikis.

\section{EMT and invasion}

EMT is a fundamental process for tumor progression by increasing invasiveness and resistance to anoikis and significantly elevating the production of extracellular matrix constituents leading to metastasis [41-43]. EMT development results in the degradation of basement membrane and formation of mesenchymal-like cells [42]. Studies have demonstrated that nervous system regulates EMT development via the release of neurotransmitters and neurotrophins [40,44]. The overexpression of TrkB or activation by BDNF in human endometrial cancer cell lines results in altered expression of EMT molecular mediators [44]. Nicotine treatment induces changes in gene expression associated with EMT in lung and breast cancer cells [40].

\section{Extravasation and colonization}

Nervous system modulates the function of vascular system which is essential for tumor cell extravasation and colonization. It has been found that neuropeptides such as substance P (SP) and bradykinin enhance vascular permeability promoting tumor cell extravasation and colonization [28, 29]. In a mouse model bearing sarcoma 180 cells, bradykinin enhances tumor-associated vascular permeability [28]. SP regulates physiological functions of vascular system including smooth muscle contractility, and vascular permeability [29]. Cell extravasation and colonization are prerequisite for angiogenesis which is a crucial step in the development of cancer metastasis.

\section{Angiogenesis}

Development of tumor angiogenesis is essential for tumor growth and progression. Vascular endothelial growth factor (VEGF) plays significant role in tumor angiogenesis, leading to metastasis [45-47]. Studies have demonstrated the important role of neurotransmitters and neuropeptides in regulating angiogenesis. In the xenograft models of ovarian cancer, chronic stress mediates the vascularization of intraperitoneal metastasis and enhances tumor angiogenesis via increasing VEGF expression $[48,49]$. In breast cancer cell lines, direct activation of $\beta$-adrenergic signaling can amplify expression of VEGF and cytokines, interleukin (IL)-6, and IL-8 that stimulate tumor angiogenesis [50]. In colon tumor tissues from HT-29 cell-bearing BALB/c mice, VEGF expression is elevated by nicotine which correlates with enhanced microvessel density [51]. Neuropeptide Y (NPY) enhances the expression of VEGF and its 
secretion promoting angiogenesis and breast cancer progression [52].

\section{Evasion of immune response}

The nervous system plays a fundamental role in regulating immune responses [53]. Inflammatory mediators can activate sensory nerves that send signals regarding inflammation to the central nervous system, which in turn leads to the release of neuromediators modulating local inflammation and influencing immune cells [54]. Since inflammatory signals are important for tumor progression in both the early and late stages, the anti-inflammatory role of the vagus nerve may play an important role in cancer metastasis [55]. $\beta$-adrenergic receptor agonist suppressed natural killer (NK) cell activity resulting in increased lung metastasis in murine metastatic mammary adenocarcinoma [56]. In addition, pharmacological or stress-associated $\beta$-adrenergic stimulation results in increased macrophage infiltration and cancer metastasis in breast cancer model [57].

\section{Tumor microenvironment}

Tumor microenvironment (mainly contain stromal cells and signal molecules) plays essential role in the formation of cancer metastasis. Stromal cells produce neural-related factors and express $\beta$-adrenergic receptor that facilitated tumor cell proliferation and survival in the primary site and secondary organ $[10,24]$. Tumor-associated macrophages play a role in $\beta$-adrenergic signaling pathways, by accelerating angiogenesis, chemokine secretion to attract tumor cells, secretion of pro-inflammatory cytokines (IL-1, IL-6, IL-8, and tumor necrosis factor (TNF)- $\alpha$ ) and escape of anti-tumor responses [58-60]. Hence, tumor microenvironment creates a feedback loop with the nervous system enabling the growth of primary and secondary tumors. Overall, these studies have demonstrated that the nervous system modulates each step of cancer metastasis through the release of neural-related factors.

\section{Role of perineural invasion in cancer metastasis}

Perineural invasion (PNI) also known as neurotropic carcinomatous spread is a process mainly categorized by neoplastic invasion of the nerves. PNI is defined as the presence of cancer cells in the perineurium; it is believed to be a common route for cancer metastasis can cause cancer-related pain [61-68]. The presence of PNI is mostly associated with poor prognosis and high recurrence in colorectal [69], gastric [64], oral tongue squamous cell carcinoma (OTSCC) [62], and pancreatic [61] cancers. In stage II and III colorectal cancer patients, the presence of PNI is associated with tumor grade, metastasis to lymph nodes and poor patient survival [63]. However, in invasive breast carcinoma the presence of PNI has been demonstrated to have no prognostic value $[67,70]$.

PNI is influenced by the interaction between the nerve microenvironment and neurotrophic molecules expressed by cancer cells such as nerve growth factor (NGF), BDNF, glial cell line-derived neurotrophic factor (GDNF) and their receptors [61, 68, 71]. A number of studies demonstrated correlation between the presence of PNI with high expression of NGF and its receptor tropomyosin related kinase A (TrkA) [61, 72, 73]. It is speculated that neurotrophins released by neural tissue act as chemotactic factors, and in cancer cells where Trks are overexpressed, they provide mechanism to invade the perineural space. High expression of NGF or TrkA and $\mathrm{P} 75^{\mathrm{NTR}}$ receptors is associated with lymph node metastasis in a mouse model of breast cancer [74]. In OTSCC patients [73], the presence of PNI and NGF is associated with larger tumor size and lymph node metastasis, suggesting that its presence can be a valuable marker to predict the disease progression and prognosis [65]. Overexpression of TrkA associates with enhanced growth, invasion and migration of breast cancer cells in vitro as well as enhanced metastasis in xenografted immunodeficient mice via the PI3K-AKT and ERK/P38 MAP kinases [75]. Conversely, immuno-histochemical evaluation of tissues from patients with extrahepatic cholangiocarcinoma shows that intra-tumoral NGF expression does not correlate with PNI, absence of disease recurrence and overall patient survival [76]. GDNF has been demonstrated to induce cancer cells migration. In human pancreatic adenocarcinoma tissues and MiaPaCa-2 cell lines, binding of GDNF to its receptor GFR $\alpha 1$ stimulates PNI via GDNF-(Ret proto-oncogene) RET signaling pathway [71]. Activation of GDNFGFR $\alpha 1-R E T$ signaling triggers the MAPK signaling pathway leading to pancreatic cancer cell migration toward nerves in both in vitro and animal models of PNI [77]. Cancer-nerve interaction studied in in vitro co-cultures of DRG and MiaPaCa-2 pancreatic cancer cells demonstrated that GFR $\alpha 1$ facilitates migration of cancer cells along neurites toward the center of the DRG [71]. Furthermore, decreased release of soluble GFR $\alpha 1$ from DRG inhibits migration of cancer cells towards nerves in vivo providing further evidence that GFR $\alpha 1$ expression is important in facilitating PNI [71]. In a metastatic breast cancer model, in vivo inhibition of Ret suppresses tumour outgrowth and metastatic potential [78].

BDNF facilitates cancer metastasis via binding to its receptors, TrkB/ TrkC and/or p75NTR as demonstrated in breast [79], colorectal [80, 81], clear cell renal cell carcinoma [82] and non-small cell lung cancer (NSCLC) [83]. The expression of TrkB associates with nodal metastasis and peritoneal metastasis; whereas, TrkC expression associates with liver metastasis in colorectal cancer 
patients [81]. BDNF-TrkB signaling pathway mediates metastatic effect through modulation of cancerassociated fibroblasts (CAFs) as demonstrated in mouse model co-injected with OSC19-Luc transfected cell line and CAFs [84]. In melanoma, neurotrophin (NT)-3, NT4 , and NGF induce cell migration, with a stronger effect on metastatic cell lines via binding to p75NTR coreceptor sortilin [85]. In breast cancer, NT-3 enhances breast cancer metastasis in the brain via promoting the mesenchymal-epithelial transition of breast cancer cells to a more epithelial-like phenotype and via increasing the ability of these cells to proliferate in the brain [86].

Collectively, these studies demonstrate that neurotrophins and their receptors play crucial role in PNI. These studies also suggest that the presence of PNI could be an effective predictor of metastatic potential and patient survival.

\section{Tumor innervation influencing cancer metastasis Tumor innervation}

Cancer-related neurogenesis (tumor innervation) is attributed to the ability of cancer cells to attract normal nerve fibers via the secretion of signalling molecules and neurotrophic factor. However, recent study has demonstrated that cancer stem cells are capable of directly initiating tumor neurogenesis [87]. Cancer stem cells derived from human gastric and colorectal cancer patients generate neurons including sympathetic and parasympathetic neurons which promote tumor progression [87]. Knocking down their neural cell generating abilities inhibit tumor growth in human xenograft mouse model. Neurogenesis and its putative regulatory mechanisms have been reported in prostate [88], gastric [89], colorectal [90] and breast [91] cancers. There is a correlation between the expression of a pan-neuronal marker protein gene product 9.5 with clinicopathological characteristics of breast cancer [91]. In fact, neurogenesis is associated with aggressive features including tumor grade, poor survival as well as angiogenesis, especially in estrogen receptor-negative and node-negative breast cancer subtypes [91, 92]. In prostate cancer, infiltration of the tumor microenvironment by nerve fibers associates with poor clinical outcomes [93] and is driven by the expression of granulocyte colony-stimulating factor (G-CSF) [94] and proNGF [95]. Similarly, in orthotopic PC3-luc xenografts model of prostate cancer, neurogenesis and axonogenesis correlate with aggressive features including metastatic spread which is attributed to the neo-cholinergic parasympathetic nerve fiber [94]. These findings indicate that neurogenesis, like angiogenesis, is also a trait of cancer invasion and can alter tumor behaviour.

\section{Tumor denervation}

On the other hand, disruption of tissue innervation might cause accelerated tumor growth and metastasis [56, 96-101]. For instance, in humans, decreased vagal nerve activity correlates with advanced stages of cancer [96-98]. Similarly, modulation of vagal nerve activity enhances metastasis of breast cancer in mice $[99,100]$. In addition, capsaicin-induced inactivation of sensory neurons enhances metastasis of breast cancer cells [56, 101]. On contrary, pharmacological or surgical denervation supresses the tumor progression as noted in three independent mice models of gastric cancer [89]. Thus, these findings suggest that there might be differences in the effects of local tumor innervation and extrinsic innervation on cancer progression.

\section{Neurotransmitters influencing cancer metastasis}

Tumor innervation influences metastasis as the ingrown nerve endings release neurotransmitters (such as norepinephrine, dopamine and substance P), which enhance metastatic spread [102]. To date, several neurotransmitters and neuropeptides involved in tumor metastasis have been identified (Table 1 and Fig. 1). In fact, several cancer cells express receptors for a number of neuropeptides and neurotransmitters, like norepinephrine, epinephrine, dopamine, GABA, acetylcholine, SP and NPY which have stimulatory effects on migration of cancer cells [103-112].

\section{Catecholamines}

The increased expression of $\beta$-adrenergic receptor for catecholamines is associated with poor prognosis in breast cancer [113]. Stress stimulation leads to macrophage infiltration to the tumor site which activates $\beta$-adrenergic signaling pathways leading to increased metastasis in an orthotopic breast cancer model in $\mathrm{BALB} / \mathrm{c}$ mice [57]. In this model, administration of $\beta$-adrenergic antagonist, propranolol, decreases breast cancer metastasis [57]. Similarly, the use of $\beta$-blockers in breast cancer patients inhibits metastasis and disease recurrence as well as improving survival of patients $[113,114]$. In ovarian cancer patients, the grade and stage of tumors correlate with higher tumor norepinephrine levels associated with stress [115]. In an orthotopic mouse model of ovarian cancer, chronic stress elevates tumor noradrenaline levels and increases the aggressiveness of tumor growth [49]. In prostate cancer $\mathrm{C} 42$ xenografts in nude mice and $\mathrm{Hi}-\mathrm{Myc}$ mice with prostate cancer, plasma adrenaline promotes carcinogenesis via $\beta_{2}$ adrenergic receptor/ protein kinase A/BCL2-associated death protein antiapoptotic signaling pathway [116]. Hence, stimulation of catecholamines plays a major role in activation of signals for breast cancer metastasis. Therefore, 


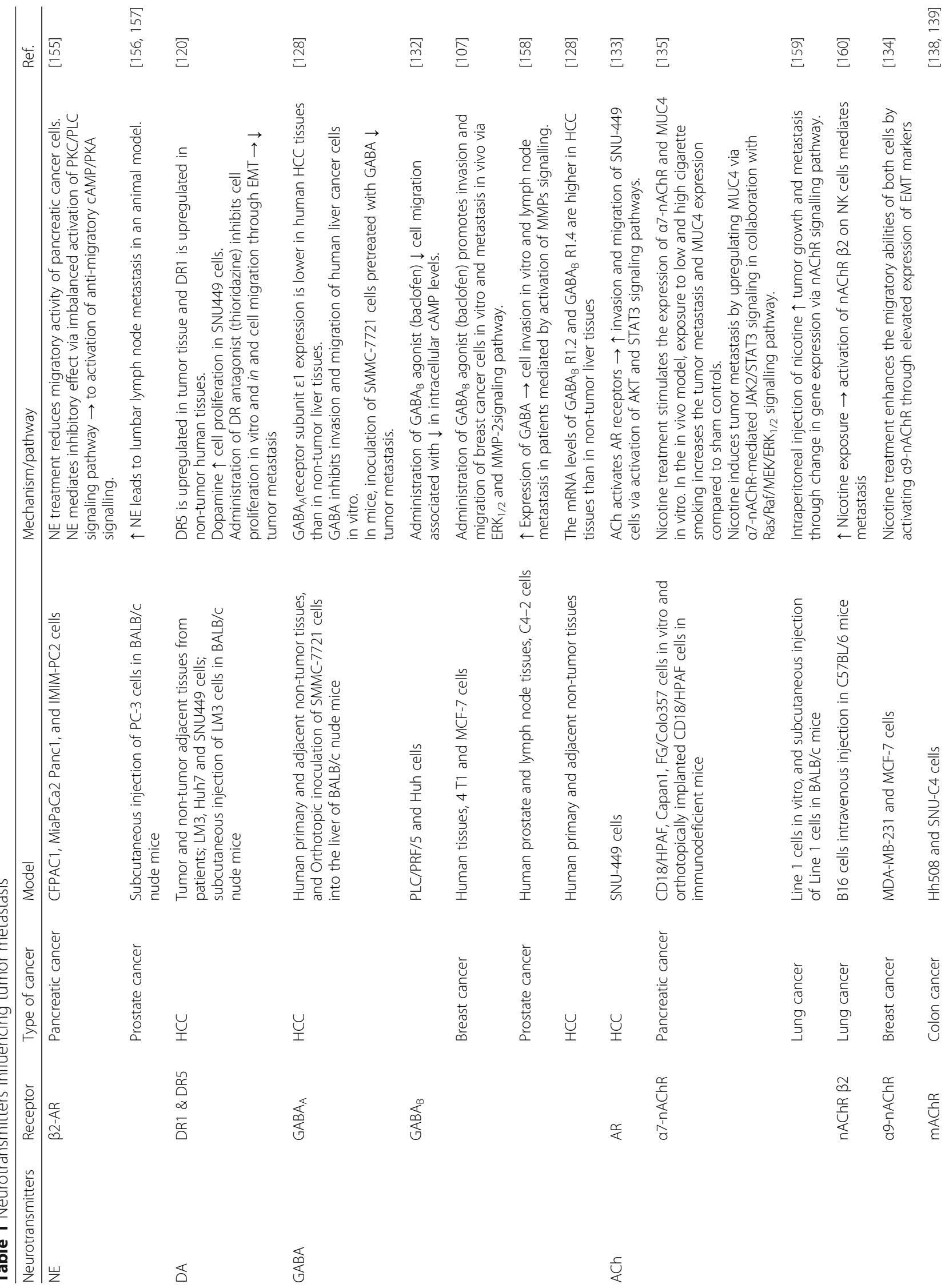




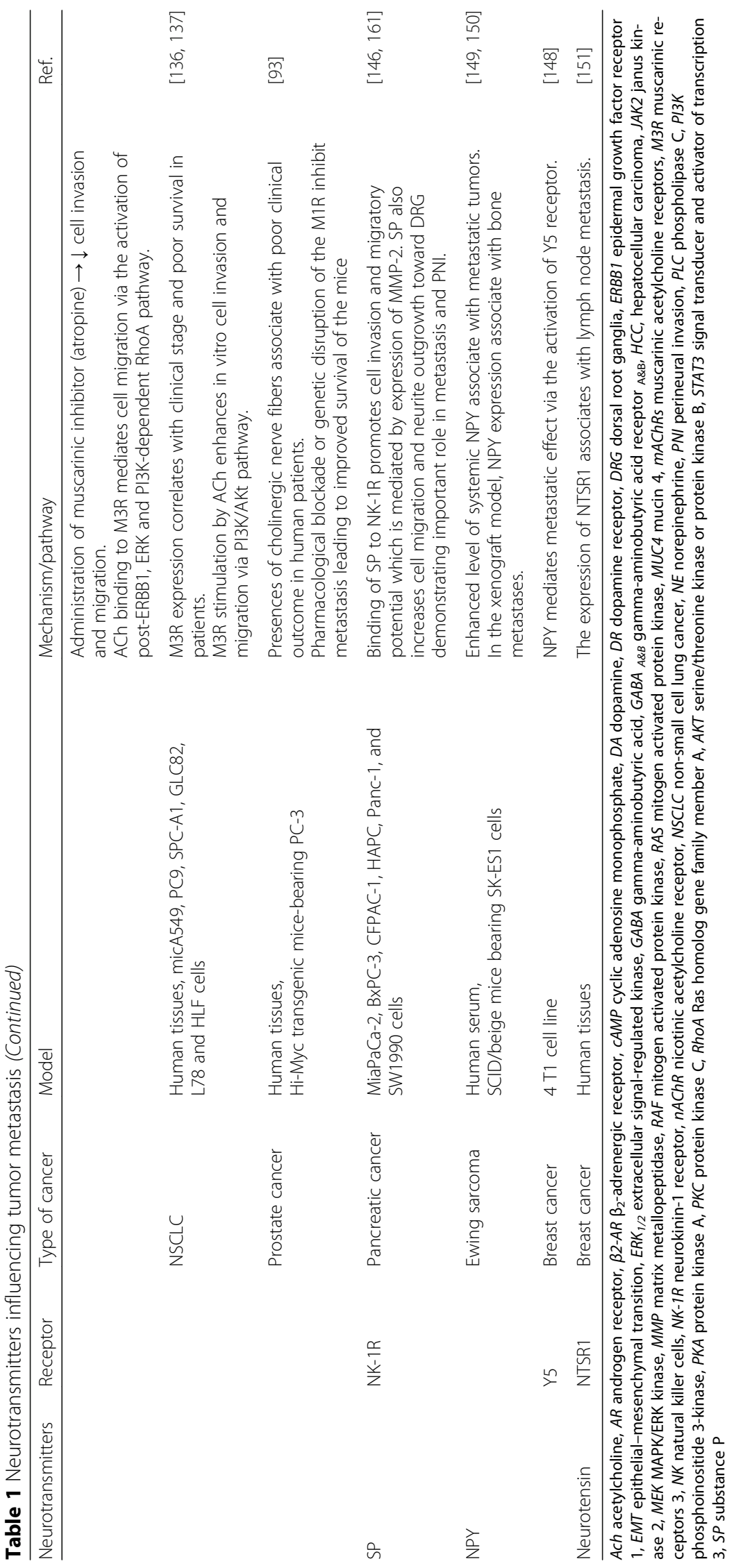




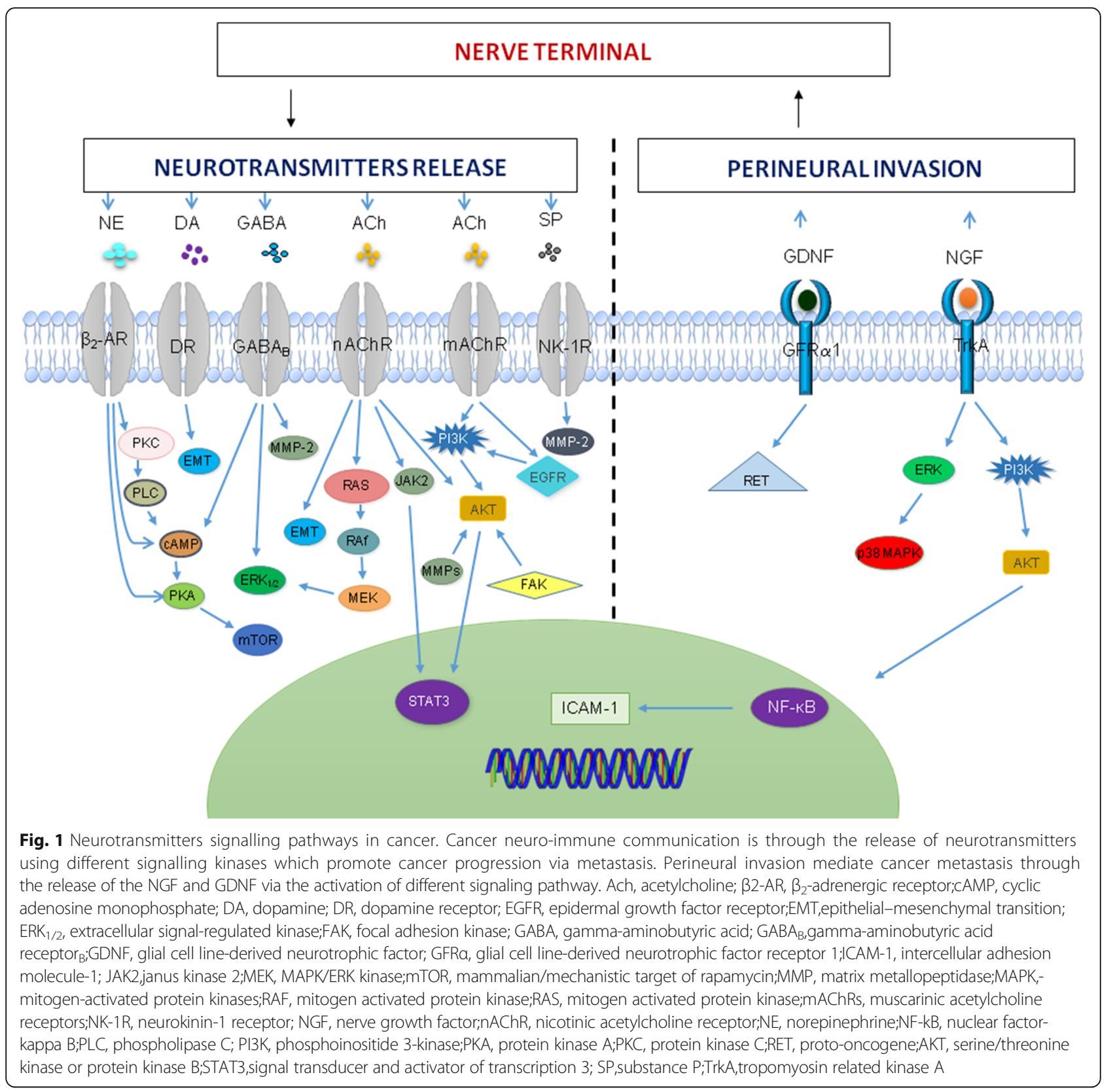

inhibition of the sympathetic nervous system signaling pathways with $\beta$-blockers holds great promise in preventing metastasis of various tumors including breast cancer. On the other hand, involvement of $\alpha$ adrenergic receptors in cancer metastasis is not well understood. In the murine model of metastatic mammary adenocarcinoma induced by $4 \mathrm{~T} 1$ cells in $\mathrm{BALB} / \mathrm{c}$ mice, activation of $\alpha_{2}$-adrenergic receptors increases tumor growth rate and the number of metastasis [117]. In contrast, blockade of $\alpha$-adrenergic receptors in the absence of stress increases distant metastasis in the orthotopic model of mammary adenocarcinoma induced by MDA-MB-231HM cell line in nude mice [118].

The role of dopamine in cancer metastasis is not clear. Low levels of dopamine have been reported in stressed mice with ovarian carcinoma [119]. In contrary, in hepatocellular carcinoma (HCC) patients dopamine levels are elevated in the blood samples compared to healthy individuals [120]. Moreover, enzymes such as monoamine oxidase A (MAOA) degrading catecholamines and serotonin [121] may also play an important role in influencing cancer metastasis [122-124]. Studies have demonstrated that 
MAOA expression is decreased in HCC patients; it suppresses HCC cell metastasis by inhibiting adrenergic and epidermal growth factor receptor (EGFR) signaling pathways [125]. Inhibition of MAOA stimulates malignant behavior in MDA-MB-231 breast cancer cells [126]. On the other hand, high expression of MAOA in human tissues correlates with poor prognostic in prostate cancer patients and increased tumor metastasis in xenograft mouse model of prostate cancer via HIF1- $\alpha$ /VEGF-A/ FOXO1/TWIST1 signaling pathway [124]. These limited studies on the role of MAOA in cancer metastasis are controversial.

\section{Y-Aminobutyric acid (GABA)}

Plays a role in cancer metastasis via activation of ionotropic $\left(\mathrm{GABA}_{\mathrm{A}}\right)$ and metabotropic $\left(\mathrm{GABA}_{\mathrm{B}}\right)$ receptors [127]. It has been demonstrated that GABA mediates its inhibitory effect through $\mathrm{GABA}_{\mathrm{A}}$ receptor. For example, HCC cell lines and human adjacent non-tumor liver tissues, express $\mathrm{GABA}_{\mathrm{A}}$ receptor. GABA inhibits $\mathrm{HCC}$ cell migration through the activation of $\mathrm{GABA}_{\mathrm{A}}$ receptor [128]. However, there are studies demonstrating that $\mathrm{GABA}_{\mathrm{A}}$ receptor enhances metastasis. The activation of $\mathrm{GABA}_{\mathrm{A}}$ receptors upregulates brain metastasis of breast cancer patients [129]. Expression of the $\mathrm{GABA}_{\mathrm{A}}$ receptor subunit, Gabra3, which is normally not present in breast epithelial cells, is increased in human metastatic breast cancer which correlated with poorer patients survival [108]. Gabra3 overexpression promotes migration and metastasis of breast cancer cells via activating serine/threonine kinase or protein kinase B (AKT) signaling pathway demonstrated in a mouse orthotopic model induced by MCF7 and MDA-MB-436 breast cancer cell lines [108]. Mechanistically, the activation of AKT signaling pathway enhances metastasis via downstream molecules such as focal adhesion kinase and MMPs [130, 131]. Therefore, it could be speculated that the effect of $\mathrm{GABA}_{\mathrm{A}}$ receptor depends on the activated downstream molecules and signalling pathways. Murine (4 T1) and human (MCF7) breast cancer cell lines and human breast cancer tissues express $\mathrm{GABA}_{\mathrm{B}}$ receptor [107]. In mice, $\mathrm{GABA}_{\mathrm{B}}$ receptor mediates $4 \mathrm{~T} 1$ cell invasion and pulmonary metastasis via $\mathrm{ERK}_{1 / 2}$ signaling [107]. $\mathrm{GABA}_{\mathrm{B}}$ activation inhibits migration of PLC/PRF/5 and Huh 7 malignant hepatocyte cell lines in vitro [132].

\section{Acetylcholine (ACh)}

Plays a functional role in cellular proliferation, differentiation and apoptosis. In HCC, the release of ACh acting on androgen receptor promotes SNU-449 cell invasion and migration via activation of AKT and signal transducer and activator of transcription 3 (STAT3) signaling pathways [133]. Nicotine stimulation of nicotinic acetylcholine receptor (nAChRs) enhances SW620 and LOVO colorectal cancer cell invasion and metastasis in vitro via the activation of p38 mitogen-activated protein kinases (MAPK) signaling pathway [112]. Similarly, nicotine pretreatment stimulates the activation of $\alpha 9$ nAChR which mediates MCF-7 and MDA-MB-231 breast cancer cell migration via the expression of epithelial mesenchymal transition markers [134]. Furthermore, implantation of CD18/HPAF pancreatic cancer cells into immuno-deficient mice, demonstrates that nicotine treatment activates $\alpha 7-\mathrm{nAChR}$ and mediates tumor metastasis via Janus kinase 2 (JAK2)/STAT3 signaling in synergy with mitogen activated protein kinase (Ras/Raf/ MEK/ERK ${ }_{1 / 2}$ ) signalling pathway [135]. ACh promoted cancer metastasis and associate with poor clinical outcomes in prostate adenocarcinoma via M1R; and pharmacological blockade or genetic disruption of the M1R inhibit tumor invasion and metastasis leading to improved survival of the mice-bearing $\mathrm{PC}-3$ prostate tumor xenografts [93]. In addition, ACh acting on M3 muscarinic receptor (M3R) associates with metastasis and low survival rate of NSCLC patients [136]. M3R activation increases invasion and migration of NSCLC cells and increased release of interleukin (IL)-8 via the activation of EGFR/PI3K/AKT pathway [137]. In human SNU-C4 and H508 colon cancer cell lines, administration of muscarinic receptor inhibitor, atropine, abolished SNU-C4 cell migration, however, H508 cell migration requires the activation of MMP7 [138, 139].

\section{Neuropeptides}

Expression of SP is shown to exert functional effects on small cell lung cancer [140], pancreatic [141], colon [142], prostate [143, 144] and breast cancer [145] cells. SP acting on neurokinin-1 (NK-1) receptors enhances pancreatic cancer cell migration and perineural invasion to the dorsal root ganglia (DRG) mediated by MMP-2 demonstrating its essential role in metastasis [146]. Enhanced expression of SP correlated with lymph node metastasis and poor prognosis in colorectal cancer patients [142]. NPY modulates cell proliferation, differentiation and survival via acting on its $G$ protein-coupled receptors designated Y1R-Y5R leading to the development of metastasis [147, 148]. High levels of systemic NPY associates with metastatic tumors as noted in Ewing sarcoma patients [149]. Similarly, in the SK-ES1 xenograft model, elevated levels of NPY associates with bone invasion and metastases [150]. NPY mediates 4 T1 cell proliferation and migration via the activation of NPY Y5 receptor [148]. Neurotensin mediates metastasis by binding to neurotensin receptors 1 (NTSR1). In breast cancer, the expression of NTSR1 correlates with lymph node metastasis [151]. These studies demonstrate the important role of neuropeptide signaling in cancer metastasis. 


\section{Concluding remarks and future directions}

Metastasis continues to be the main cause of cancerrelated death. Although genetic compartments that influence metastasis have been identified, there are still needs to conduct comprehensive evaluation of the factors that contribute to cancer metastasis. This review demonstrates that the nervous system influences cancer metastasis through the release of neurotransmitters and neuropeptides leading to metastasis. However, sensory nerve fibres have been given less attention. Sensory stimuli activate pain transmission pathways which result in acute or chronic pain depending on the intensity and the nature of the stimulus [152, 153]. Cancer-related pain is linked to accelerating cancer progression and metastasis. Sensory nerves can innervate primary tumors and metastases, thus contributing to tumor-associated pain as demonstrated in pancreatic [61] and prostate cancer [154]. Therefore, a possible involvement of sensory fibers in tumor progression and metastasis, although not well demonstrated at this stage, cannot be excluded.

In conclusion, cancer cells can transduce neurotransmittermediated intracellular signaling pathways which lead to their activation, growth and metastasis. The findings reported here are primarily done in cancer cell lines and animal models. Therefore, better understanding the interaction between these signaling molecules and tumor cells in human cancers would enhance our knowledge on pathways promoting cancer metastasis.

\section{Acknowledgements}

NK was supported by an Australian Postgraduate Research Award, LS and KN was supported by the College of Heath and Biomedicine Victoria University, Australia and VA was supported by the Centre for Chronic Disease, Victoria University, Australia.

\section{Authors' contributions}

NK wrote the manuscript. LS, VA and KN revised and corrected the manuscript. All authors read and approved the final manuscript.

\section{Competing interests}

The authors confirm that this article content has not competing interests.

\section{Publisher's Note}

Springer Nature remains neutral with regard to jurisdictional claims in published maps and institutional affiliations.

Received: 29 October 2017 Accepted: 30 December 2017

Published online: 15 January 2018

\section{References}

1. Torre LA, Bray F, Siegel RL, Ferlay J, Lortet-Tieulent J, Jemal A. Global cancer statistics, 2012. CA Cancer J Clin. 2015;65(2):87-108.

2. Fisher E, Fisher B. Recent observations on concepts of metastasis. Arch Pathol. 1967;83(4):321.

3. Fidler IJ. The pathogenesis of cancer metastasis: the'seed and soil'hypothesis revisited. Nat Rev Cancer. 2003;3(6):453-8.

4. Folkman J. Angiogenesis: an organizing principle for drug discovery? Nat Rev Drug Discov. 2007;6(4):273-86.

5. Moreno-Smith M, Lutgendorf SK, Sood AK. Impact of stress on cancer metastasis. Future Oncol. 2010;6(12):1863-81.
6. Hynes RO. Metastatic potential: generic predisposition of the primary tumor or rare, metastatic variants_or both? Cell. 2003;113(7):821-3.

7. Nguyen DX, Massagué J. Genetic determinants of cancer metastasis. Nat Rev Genet. 2007;8(5):341-52.

8. Ramaswamy S, Ross KN, Lander ES, Golub TR. A molecular signature of metastasis in primary solid tumors. Nat Genet. 2003;33(1):49-54.

9. Hynes RO. Metastatic potential: generic predisposition of the primary tumor or rare, metastatic variants or both? Cell. 2003;113(7):821-3.

10. Quail DF, Joyce JA. Microenvironmental regulation of tumor progression and metastasis. Nat Med. 2013;19(11):1423-37.

11. Gupta GP, Massagué J. Cancer Metastasis: building a framework. Cell. 2006; 127(4):679-95.

12. Place $A E$, Jin Huh $S$, Polyak K. The microenvironment in breast cancer progression: biology and implications for treatment. Breast Cancer Res. 2011;13(6):227.

13. Miller S, Senior PV, Prakash M, Apostolopoulos V, Sakkal S, Nurgali K. Leukocyte populations and IL-6 in the tumor microenvironment of an orthotopic colorectal cancer model. Acta Biochim Biophys Sin. 2016:48(4): 334-41.

14. Markwell SM, Weed SA. Tumor and Stromal-based contributions to head and neck Squamous cell carcinoma invasion. Cancers. 2015;7(1):382-406.

15. Liguori M, Solinas G, Germano G, Mantovani A, Allavena P. Tumorassociated macrophages as incessant builders and destroyers of the cancer stroma. Cancers. 2011;3(4):3740-61.

16. Sun Y. Translational horizons in the tumor microenvironment: harnessing breakthroughs and targeting cures. Med Res Rev. 2015;35(2):408-36.

17. Hanahan D, Coussens LM. Accessories to the crime: functions of cells recruited to the tumor microenvironment. Cancer Cell. 2012;21(3):309-22.

18. Hanahan D, Weinberg RA. Hallmarks of cancer: the next generation. Cell. 2011;144(5):646-74.

19. Joyce JA, Pollard JW. Microenvironmental regulation of metastasis. Nat Rev Cancer. 2009:9(4):239-52

20. Schmid MC, Varner JA. Myeloid cells in the tumor microenvironment: modulation of tumor angiogenesis and tumor inflammation. J Oncol. 2010;2010

21. Li S, Sun Y, Gao D. Role of the nervous system in cancer metastasis (review). Oncol Lett. 2013;5(4):1101-11.

22. Voss MJ, Entschladen F. Tumor interactions with soluble factors and the nervous system. Cell Commun Signal. 2010;8:21.

23. Chang A, Kim-Fuchs C, Le CP, Hollande F, Sloan EK. Neural regulation of pancreatic cancer: a novel target for intervention. Cancers. 2015;7(3):1292-312.

24. Cole SW, Sood AK. Molecular pathways: beta-adrenergic signaling in cancer. Clin Cancer Res. 2012;18(5):1201-6.

25. Ondicova K, Mravec B. Role of nervous system in cancer aetiopathogenesis. Lancet Oncol. 2010;11(6):596-601.

26. Mravec B, Gidron Y, Hulin I. Neurobiology of cancer: interactions between nervous, endocrine and immune systems as a base for monitoring and modulating the tumorigenesis by the brain. Semin Cancer Biol. 2008;18(3): 150-63.

27. Douma S, van Laar T, Zevenhoven J, Meuwissen R, van Garderen E, Peeper DS. Suppression of anoikis and induction of metastasis by the neurotrophic receptor TrkB. Nature. 2004;430:1034.

28. Ishihara K, Kamata M, Hayashi I, Yamashina S, Majima M. Roles of bradykinin in vascular permeability and angiogenesis in solid tumor. Int Immunopharmacol. 2002;2(4):499-509.

29. O'Connor TM, O'Connell J, O'Brien DI, Goode T, Bredin CP, Shanahan F. The role of substance $P$ in inflammatory disease. J Cell Physiol. 2004; 201(2):167-80.

30. Celià-Terrassa T, Kang Y. Distinctive properties of metastasis-initiating cells. Genes Dev. 2016;30(8):892-908

31. MacDougall JR, Matrisian LM. Contributions of tumor and stromal matrix metalloproteinases to tumor progression, invasion and metastasis. Cancer Metastasis Rev. 1995;14(4):351-62.

32. Deryugina El, Quigley JP. Matrix metalloproteinases and tumor metastasis. Cancer Metastasis Rev. 2006;25(1):9-34.

33. Okada Y, Eibl G, Guha S, Duffy JP, Reber HA, Hines OJ. Nerve growth factor stimulates MMP-2 expression and activity and increases invasion by human pancreatic cancer cells. Clin Exp Metastasis. 2004;21(4):285-92.

34. Okada Y, Eibl G, Duffy JP, Reber HA, Hines OJ. Glial cell-derived neurotrophic factor upregulates the expression and activation of matrix metalloproteinase-9 in human pancreatic cancer. Surgery. 2003;134(2):293-9. 
35. Yang EV, Sood AK, Chen M, Li Y, Eubank TD, Marsh CB, Jewell S, Flavahan NA, Morrison $C_{\text {, }}$ Yeh $\mathrm{PE}$, et al. Norepinephrine up-regulates the expression of vascular endothelial growth factor, matrix metalloproteinase (MMP)-2, and MMP-9 in nasopharyngeal carcinoma tumor cells. Cancer Res. 2006; 66(21):10357-64

36. Simpson CD, Anyiwe K, Schimmer AD. Anoikis resistance and tumor metastasis. Cancer Lett. 2008;272(2):177-85.

37. Paoli P, Giannoni E, Chiarugi P. Anoikis molecular pathways and its role in cancer progression. Biochim Biophys Acta (BBA) - Mol Cell Res. 2013; 1833(12):3481-98

38. Fan M, Sun J, Wang W, Fan J, Wang L, Zhang X, Yang A, Wang W, Zhang R, Li J. Tropomyosin-related kinase B promotes distant metastasis of colorectal cancer through protein kinase B-mediated anoikis suppression and correlates with poor prognosis. Apoptosis. 2014;19(5):860-70.

39. Okugawa Y, Tanaka K, Inoue Y, Kawamura M, Kawamoto A, Hiro J, Saigusa S, Toiyama Y, Ohi M, Uchida K, et al. Brain-derived neurotrophic factor/ tropomyosin-related kinase B pathway in gastric cancer. Br J Cancer. 2012;108:121

40. Dasgupta P, Rizwani W, Pillai S, Kinkade R, Kovacs M, Rastogi S, Banerjee S, Carless M, Kim E, Coppola D, et al. Nicotine induces cell proliferation, invasion and epithelial-mesenchymal transition in a variety of human cancer cell lines. Int J Cancer. 2009;124(1):36-45.

41. Mani SA, Guo W, Liao MJ, Eaton EN, Ayyanan A, Zhou AY, Brooks M, Reinhard F, Zhang CC, Shipitsin M, et al. The epithelial-mesenchymal transition generates cells with properties of stem cells. Cell. 2008;133(4):704-15.

42. Kalluri R, Weinberg RA. The basics of epithelial-mesenchymal transition. J Clin Invest. 2009;119(6):1420-8.

43. Polyak K, Weinberg RA. Transitions between epithelial and mesenchymal states: acquisition of malignant and stem cell traits. Nat Rev Cancer. 2009; 9(4):265-73.

44. Bao W, Qiu H, Yang T, Luo X, Zhang H, Wan X. Upregulation of TrkB promotes epithelial-Mesenchymal transition and Anoikis resistance in endometrial carcinoma. PLoS One. 2013;8(7):e70616.

45. Park SY, Kang JH, Jeong KJ, Lee J, Han JW, Choi WS, Kim YK, Kang J, Park CG, Lee HY. Norepinephrine induces VEGF expression and angiogenesis by a hypoxia-inducible factor-1alpha protein-dependent mechanism. Int J Cancer. 2011;128(10):2306-16.

46. Toda M, Suzuki T, Hosono K, Hayashi I, Hashiba S, Onuma Y, Amano H, Kurihara $\mathrm{Y}$, Kurihara $\mathrm{H}$, Okamoto $\mathrm{H}$, et al. Neuronal system-dependent facilitation of tumor angiogenesis and tumor growth by calcitonin generelated peptide. Proc Natl Acad Sci U S A. 2008;105(36):13550-5.

47. Lee EW, Michalkiewicz M, Kitlinska J, Kalezic I, Switalska H, Yoo P, Sangkharat A, $\mathrm{Ji} \mathrm{H}$, Li L, Michalkiewicz T, et al. Neuropeptide $Y$ induces ischemic angiogenesis and restores function of ischemic skeletal muscles. J Clin Invest. 2003;111(12): 1853-62.

48. Lutgendorf SK, Cole S, Costanzo E, Bradley S, Coffin J, Jabbari S, Rainwater K, Ritchie JM, Yang M, Sood AK. Stress-related mediators stimulate vascular endothelial growth factor secretion by two ovarian cancer cell lines. Clin Cancer Res. 2003:9(12):4514-21.

49. Thaker PH, Han LY, Kamat AA, Arevalo JM, Takahashi R, Lu C, Jennings NB, Armaiz-Pena G, Bankson JA, Ravoori M. Chronic stress promotes tumor growth and angiogenesis in a mouse model of ovarian carcinoma. Nat Med. 2006;12(8):939-44.

50. Madden KS, Szpunar MJ, Brown EB. Beta-adrenergic receptors (beta-AR) regulate VEGF and IL-6 production by divergent pathways in high betaAR-expressing breast cancer cell lines. Breast Cancer Res Treat. 2011 ; 130(3):747-58

51. Wong HPS, Yu L, Lam EKY, Tai EKK, Wu WKK, Cho C-H. Nicotine promotes colon tumor growth and angiogenesis through $\beta$-adrenergic activation. Toxicol Sci. 2007;97(2):279-87.

52. Medeiros PJ, Jackson DN. Neuropeptide Y Y5-receptor activation on breast cancer cells acts as a paracrine system that stimulates VEGF expression and secretion to promote angiogenesis. Peptides. 2013;48:106-13.

53. Kuol N, Stojanovska L, Apostolopoulos V, Nurgali K. Crosstalk between cancer and the neuro-immune system. J Neuroimmunol. 2017:315:15-23.

54. Tracey KJ. Reflex control of immunity. Nat Rev Immunol. 2009;9(6):418-28.

55. Gidron $Y$, Perry $H$, Glennie $M$. Does the vagus nerve inform the brain about preclinical tumours and modulate them? Lancet Oncol. 2005;6(4):245-8.

56. Erin N, Boyer PJ, Bonneau RH, Clawson GA, Welch DR. Capsaicin-mediated denervation of sensory neurons promotes mammary tumor metastasis to lung and heart. Anticancer Res. 2004;24(2B):1003-10.
57. Sloan EK, Priceman SJ, Cox BF, Yu S, Pimentel MA, Tangkanangnukul V, Arevalo JM, Morizono K, Karanikolas BD, Wu L. The sympathetic nervous system induces a metastatic switch in primary breast cancer. Cancer Res. 2010;70(18):7042-52.

58. DeNardo DG, Brennan DJ, Rexhepaj E, Ruffell B, Shiao SL, Madden SF, Gallagher WM, Wadhwani N, Keil SD, Junaid SA. Leukocyte complexity predicts breast cancer survival and functionally regulates response to chemotherapy. Cancer Discov. 2011;1(1):54-67.

59. DeNardo DG, Coussens LM. Balancing immune response: crosstalk between adaptive and innate immune cells during breast cancer progression. Breast Cancer Res. 2007:9(4):212.

60. Mantovani A, Allavena P, Sica A, Balkwill F. Cancer-related inflammation. Nature. 2008;454(7203):436-44.

61. Bapat AA, Hostetter G, Von Hoff DD, Han H. Perineural invasion and associated pain in pancreatic cancer. Nat Rev Cancer. 2011;11(10):695-707.

62. Matsushita Y, Yanamoto S, Takahashi H, Yamada S, Naruse T, Sakamoto Y, Ikeda H, Shiraishi T, Fujita S, Ikeda T, et al. A clinicopathological study of perineural invasion and vascular invasion in oral tongue squamous cell carcinoma. Int J Oral Maxillofac Surg. 2015;44(5):543-8.

63. Zhou Y, Wang H, Gong H, Cao M, Zhang G, Wang Y. Clinical significance of perineural invasion in stages $\mathrm{II}$ and III colorectal cancer. Pathol-Res Pract. 2015;211(11):839-44.

64. Zhou Z-H, Xu G-F, Zhang W-J, Zhao H-B, Wu Y-Y. Reevaluating significance of perineural invasion in gastric cancer based on double immunohistochemical staining. Arch Pathol Lab Med. 2014;138(2):229-34.

65. Shen WR, Wang YP, Chang JYF, Yu SY, Chen HM, Chiang CP. Perineural invasion and expression of nerve growth factor can predict the progression and prognosis of oral tongue squamous cell carcinoma. J Oral Pathol Med. 2014;43(4):258-64

66. Yu EH, Lui MT, Tu HF, Wu CH, Lo WL, Yang CC, Chang KW, Kao SY. Oral carcinoma with perineural invasion has higher nerve growth factor expression and worse prognosis. Oral Dis. 2014;20(3):268-74.

67. Karak SG, Quatrano N, Buckley J, Ricci A Jr. Prevalence and significance of perineural invasion in invasive breast carcinoma. Conn Med. 2010;74(1):17-21.

68. Marchesi F, Piemonti L, Mantovani A, Allavena P. Molecular mechanisms of perineural invasion, a forgotten pathway of dissemination and metastasis. Cytokine Growth Factor Rev. 2010;21(1):77-82.

69. Liebig C, Ayala G, Wilks J, Verstovsek G, Liu H, Agarwal N, Berger DH, Albo $D$. Perineural invasion is an independent predictor of outcome in colorectal cancer. J Clin Oncol. 2009;27(31):5131-7.

70. Duraker N, Caynak Z, Türköz K. Perineural invasion has no prognostic value in patients with invasive breast carcinoma. Breast. 2006;15(5):629-34.

71. He S, Chen C-H, Chernichenko N, He S, Bakst RL, Barajas F, Deborde S, Allen PJ, Vakiani E, Yu Z. GFRa1 released by nerves enhances cancer cell perineural invasion through GDNF-RET signaling. Proc Natl Acad Sci. 2014; 111(19):E2008-17.

72. Ma J, Jiang $Y$, Jiang $Y$, Sun $Y$, Zhao X. Expression of nerve growth factor and tyrosine kinase receptor a and correlation with perineural invasion in pancreatic cancer. J Gastroenterol Hepatol. 2008;23(12):1852-9.

73. Kolokythas A, Cox DP, Dekker N, Schmidt BL. Nerve growth factor and tyrosine kinase a receptor in oral squamous cell carcinoma: is there an association with perineural invasion? J Oral Maxillofac Surg. 2010; 68(6):1290-5

74. Zhang J, Wang L-S, Ye S-L, Luo P, Wang B-L. Blockage of tropomyosin receptor kinase a (TrkA) enhances chemo-sensitivity in breast cancer cells and inhibits metastasis in vivo. Int J Clin Exp Med. 2015;8(1):634.

75. Lagadec C, Meignan S, Adriaenssens E, Foveau B, Vanhecke E, Romon R, Toillon R-A, Oxombre B, Hondermarck H, Le Bourhis X. TrkA overexpression enhances growth and metastasis of breast cancer cells. Oncogene. 2009; 28(18):1960-70.

76. Urabe K, Murakami Y, Kondo N, Uemura K, Hashimoto Y, Nakagawa N, Sasaki H, Hiyama E, Takahashi S, Sueda T. Nerve growth factor expression is not associated with perineural invasion in extrahepatic cholangiocarcinoma. Dig Dis Sci. 2015:1-11.

77. Gil Z, Cavel O, Kelly K, Brader P, Rein A, Gao SP, Carlson DL, Shah JP, Fong Y, Wong RJ. Paracrine regulation of pancreatic cancer cell invasion by peripheral nerves. J Natl Cancer Inst. 2010;102(2):107-18.

78. Gattelli A, Nalvarte I, Boulay A, Roloff TC, Schreiber M, Carragher N, Macleod KK, Schlederer M, Lienhard S, Kenner L, et al. Ret inhibition decreases growth and metastatic potential of estrogen receptor positive breast cancer cells. EMBO Mol Med. 2013;5(9):1335-50. 
79. Kim MS, Lee WS, Jin W. TrkB promotes breast cancer metastasis via suppression of Runx3 and Keap1 expression. Mol Cells. 2016;39(3):258-65.

80. Tanaka K, Okugawa Y, Toiyama Y, Inoue Y, Saigusa S, Kawamura M, Araki T, Uchida K, Mohri Y, Kusunoki M. Brain-derived neurotrophic factor (BDNF)induced tropomyosin-related kinase B (Trk B) signaling is a potential therapeutic target for peritoneal carcinomatosis arising from colorectal cancer. PLoS One. 2014;9(5):e96410.

81. Sasahira T, Ueda N, Kurihara M, Matsushima S, Ohmori H, Fujii K, Bhawal UK, Yamamoto K, Kirita T, Kuniyasu H. Tropomyosin receptor kinases B and C are tumor progressive and metastatic marker in colorectal carcinoma. Hum Pathol. 2013;44(6):1098-106.

82. De la Cruz-Morcillo MA, Berger J, Sánchez-Prieto R, Saada S, Naves T, Guillaudeau A, Perraud A, Sindou P, Lacroix A, Descazeaud A, et al. p75 neurotrophin receptor and pro-BDNF promote cell survival and migration in clear cell renal cell carcinoma. Oncotarget. 2016;7(23):34480-97.

83. Zhang S, Guo D, Luo W, Zhang Q, Zhang Y, Li C, Lu Y, Cui Z, Qiu X. TrkB is highly expressed in NSCLC and mediates BDNF-induced the activation of Pyk2 signaling and the invasion of A549 cells. BMC Cancer. 2010;10:43.

84. Jiffar T, Yilmaz T, Lee J, Miller Y, Feng L, El-Naggar A, Kupferman ME. Brain derived neutrophic factor (BDNF) coordinates lympho-vascular metastasis through a fibroblast-governed paracrine axis in the tumor microenvironment. Cancer Cell Microenvironment. 2017;4(2):e1566.

85. Truzzi F, Marconi A, Lotti R, Dallaglio K, French LE, Hempstead BL, Pincelli C. Neurotrophins and their receptors stimulate melanoma cell proliferation and migration. J Invest Dermatol. 2008;128(8):2031-40.

86. Louie E, Chen XF, Coomes A, Ji K, Tsirka S, Chen El. Neurotrophin-3 modulates breast cancer cells and the microenvironment to promote the growth of breast cancer brain metastasis. Oncogene. 2013;32(35):4064-77.

87. Lu R, Fan C, Shangguan W, Liu Y, Li Y, Shang Y, Yin D, Zhang S, Huang Q, Li $X$, et al. Neurons generated from carcinoma stem cells support cancer progression. Signal Transduct Target Ther. 2017;2:16036.

88. Ayala GE, Dai H, Powell M, Li R, Ding Y, Wheeler TM, Shine D, Kadmon D, Thompson T, Miles BJ, et al. Cancer-related axonogenesis and neurogenesis in prostate cancer. Clin Cancer Res. 2008;14(23):7593-603.

89. Zhao CM, Hayakawa Y, Kodama Y, Muthupalani S, Westphalen CB, Andersen GT, Flatberg A, Johannessen H, Friedman RA, Renz BW, et al. Denervation suppresses gastric tumorigenesis. Sci Transl Med. 2014;6(250):250ra115.

90. Albo D, Akay CL, Marshall CL, Wilks JA, Verstovsek G, Liu H, Agarwal N, Berger $\mathrm{DH}$, Ayala GE. Neurogenesis in colorectal cancer is a marker of aggressive tumor behavior and poor outcomes. Cancer. 2011;117(21):4834-45.

91. Zhao Q, Yang Y, Liang X, Du G, Liu L, Lu L, Dong J, Han H, Zhang G. The clinicopathological significance of neurogenesis in breast cancer. BMC Cancer. 2014;14:484.

92. Pundavela J, Roselli S, Faulkner S, Attia J, Scott RJ, Thorne RF, Forbes JF, Bradshaw RA, Walker MM, Jobling $P$, et al. Nerve fibers infiltrate the tumor microenvironment and are associated with nerve growth factor production and lymph node invasion in breast cancer. Mol Oncol. 2015;9(8):1626-35.

93. Magnon C, Hall SJ, Lin J, Xue X, Gerber L, Freedland SJ, Frenette PS. Autonomic nerve development contributes to prostate cancer progression. Science (New York, NY). 2013;341(6142):1236361.

94. Dobrenis K, Gauthier LR, Barroca V, Magnon C. Granulocyte colonystimulating factor off-target effect on nerve outgrowth promotes prostate cancer development. Int J Cancer. 2015;136(4):982-8.

95. Pundavela J, Demont Y, Jobling P, Lincz LF, Roselli S, Thorne RF, Bond D, Bradshaw RA, Walker MM, Hondermarck H. ProNGF correlates with Gleason score and is a potential driver of nerve infiltration in prostate cancer. Am J Pathol. 2014:184(12):3156-62

96. De Couck M, Gidron Y. Norms of vagal nerve activity, indexed by heart rate variability, in cancer patients. Cancer Epidemiol. 2013:37(5):737-41.

97. Ohira H, Matsunaga M, Osumi T, Fukuyama S, Shinoda J, Yamada J, Gidron Y. Vagal nerve activity as a moderator of brain-immune relationships. J Neuroimmunol. 2013;260(1):28-36.

98. De Couck M, Maréchal R, Moorthamers S, Van Laethem J-L, Gidron Y. Vagal nerve activity predicts overall survival in metastatic pancreatic cancer, mediated by inflammation. Cancer Epidemiol. 2016;40:47-51.

99. Erin N, Korcum AF, Tanriover G, Kale S, Demir N, Koksoy S. Activation of neuroimmune pathways increases therapeutic effects of radiotherapy on poorly differentiated breast carcinoma. Brain Behav Immun. 2015:48:174-85.

100. Erin N, Barkan GA, Harms JF, Clawson GA. Vagotomy enhances experimental metastases of 4THMpc breast cancer cells and alters substance P level. Regul Pept. 2008;151(1):35-42.
101. Erin N, Zhao W, Bylander J, Chase G, Clawson G. Capsaicin-induced inactivation of sensory neurons promotes a more aggressive gene expression phenotype in breast cancer cells. Breast Cancer Res Treat. 2006; 99(3):351-64.

102. Magnon C. Role of the autonomic nervous system in tumorigenesis and metastasis. Mol Cell Oncol. 2015;2(2):e975643.

103. Drell T IV, Joseph J, Lang K, Niggemann B, Zaenker K, Entschladen F. Effects of neurotransmitters on the chemokinesis and chemotaxis of MDA-MB-468 human breast carcinoma cells. Breast Cancer Res Treat. 2003;80(1):63-70.

104. Rodriguez PL, Jiang S, Fu Y, Avraham S, Avraham HK. The proinflammatory peptide substance $P$ promotes blood-brain barrier breaching by breast cancer cells through changes in microvascular endothelial cell tight junctions. Int J Cancer. 2014;134(5):1034-44.

105. Luthy IA, Bruzzone A, Piñero CP, Castillo L, Chiesa I, Vazquez S, Sarappa M. Adrenoceptors: non conventional target for breast cancer? Curr Med Chem. 2009;16(15):1850-62.

106. Garcia-Recio S, Fuster G, Fernandez-Nogueira P, Pastor-Arroyo EM, Park SY, Mayordomo C, Ametller E, Mancino M, Gonzalez-Farre X, Russnes HG. Substance $P$ autocrine signaling contributes to persistent HER2 activation that drives malignant progression and drug resistance in breast cancer. Cancer Res. 2013;73(21):6424-34

107. Zhang D, Li X, Yao Z, Wei C, Ning N, Li J. GABAergic signaling facilitates breast cancer metastasis by promoting ERK 1/2-dependent phosphorylation. Cancer Lett. 2014;348(1):100-8.

108. Gumireddy K, Li A, Kossenkov AV, Sakurai M, Yan J, Li Y, Xu H, Wang J, Zhang PJ, Zhang L. The mRNA-edited form of GABRA3 suppresses GABRA3mediated Akt activation and breast cancer metastasis. Nat Commun. 2016;7

109. Munoz M, Coveñas R. Involvement of substance $P$ and the NK-1 receptor in cancer progression. Peptides. 2013;48:1-9.

110. Yang T, He W, Cui F, Xia J, Zhou R, Wu Z, Zhao Y, Shi M. MACC1 mediates acetylcholine-induced invasion and migration by human gastric cancer cells. Oncotarget. 2016;7(14):18085-94.

111. Hanaki T, Horikoshi Y, Nakaso K, Nakasone M, Kitagawa Y, Amisaki M, Arai Y, Tokuyasu N, Sakamoto T, Honjo S, et al. Nicotine enhances the malignant potential of human pancreatic cancer cells via activation of atypical protein kinase C. Biochim Biophys Acta Gen Subj. 2016;1860(11):2404-15.

112. Xiang T, Fei R, Wang Z, Shen Z, Qian J, Chen W. Nicotine enhances invasion and metastasis of human colorectal cancer cells through the nicotinic acetylcholine receptor downstream p38 MAPK signaling pathway. Onco Rep. 2016;35(1):205-10.

113. Powe DG, Entschladen F. Targeted therapies: using $\beta$-blockers to inhibit breast cancer progression. Nat Rev Clin Oncol. 2011;8(9):511-2.

114. Powe DG, Voss MJ, Zänker KS, Habashy HO, Green AR, Ellis IO, Entschladen F. Beta-blocker drug therapy reduces secondary cancer formation in breast cancer and improves cancer specific survival. Oncotarget. 2010;1(7):628-38.

115. Lutgendorf SK, DeGeest K, Dahmoush L, Farley D, Penedo F, Bender D, Goodheart M, Buekers TE, Mendez L, Krueger G. Social isolation is associated with elevated tumor norepinephrine in ovarian carcinoma patients. Brain Behav Immun. 2011;25(2):250-5.

116. Hassan S, Karpova Y, Baiz D, Yancey D, Pullikuth A, Flores A, Register T, Cline JM, D'Agostino R Jr, Danial N. Behavioral stress accelerates prostate cancer development in mice. J Clin Invest. 2013;123(2):874.

117. Szpunar MJ, Burke KA, Dawes RP, Brown EB, Madden KS. The antidepressant desipramine and a2-adrenergic receptor activation promote breast tumor progression in association with altered collagen structure. Cancer Prev Res. 2013;6(12):1262-72.

118. Lamkin DM, Sung HY, Yang GS, David JM, Ma JC, Cole SW, Sloan EK. a 2adrenergic blockade mimics the enhancing effect of chronic stress on breast cancer progression. Psychoneuroendocrinology. 2015;51:262-70.

119. Moreno-Smith M, Lu C, Shahzad MM, Pena GNA, Allen JK, Stone RL Mangala LS, Han HD, Kim HS, Farley D. Dopamine blocks stress-mediated ovarian carcinoma growth. Clin Cancer Res. 2011;17(11):3649-59.

120. Lu M, Li J, Luo Z, Zhang S, Xue S, Wang K, Shi Y, Zhang C, Chen H, Li Z. Roles of dopamine receptors and their antagonist thioridazine in hepatoma metastasis. OncoTargets Ther. 2015;8:1543-52.

121. Flamand $\mathrm{V}$, Zhao $\mathrm{H}$, Peehl DM. Targeting monoamine oxidase a in advanced prostate cancer. J Cancer Res Clin Oncol. 2010;136(11):1761-71.

122. Kimura R, Kasamatsu A, Koyama T, Fukumoto C, Kouzu Y, Higo M, EndoSakamoto Y, Ogawara K, Shiiba M, Tanzawa H. Glutamate acid decarboxylase 1 promotes metastasis of human oral cancer by $\beta$-catenin translocation and MMP7 activation. BMC Cancer. 2013;13(1):555. 
123. Liu G, Zhu J, Yu M, Cai C, Zhou Y, Yu M, Fu Z, Gong Y, Yang B, Li Y, et al. Glutamate dehydrogenase is a novel prognostic marker and predicts metastases in colorectal cancer patients. J Transl Med. 2015;13

124. Wu JB, Shao C, Li X, Li Q, Hu P, Shi C, Li Y, Chen YT, Yin F, Liao CP, et al. Monoamine oxidase a mediates prostate tumorigenesis and cancer metastasis. J Clin Invest. 2014;124(7):2891-908.

125. Li J, Yang X-M, Wang Y-H, Feng M-X, Liu X-J, Zhang Y-L, Huang S, Wu Z, Xue F, Qin W-X, et al. Monoamine oxidase a suppresses hepatocellular carcinoma metastasis by inhibiting the adrenergic system and its transactivation of EGFR signaling. J Hepatol. 2014;60(6):1225-34.

126. Satram-Maharaj T, Nyarko JN, Kuski K, Fehr K, Pennington PR, Truitt L, Freywald A, Lukong KE, Anderson DH, Mousseau DD. The monoamine oxidase-a inhibitor clorgyline promotes a mesenchymal-to-epithelial transition in the MDA-MB-231 breast cancer cell line. Cell Signal. 2014; 26(12):2621-32.

127. Owens DF, Kriegstein AR. Is there more to GABA than synaptic inhibition? Nat Rev Neurosci. 2002;3(9):715-27.

128. Z-a C, Bao M-y, Xu Y-f, R-p Z, H-b S, T-y C, He X-h. Suppression of human liver cancer cell migration and invasion via the GABAA receptor. Cancer Biol Med. 2012;9(2):90.

129. Neman J, Termini J, Wilczynski S, Vaidehi N, Choy C, Kowolik CM, Li H, Hambrecht AC, Roberts E, Jandial R. Human breast cancer metastases to the brain display GABAergic properties in the neural niche. Proc Natl Acad Sci. 2014;111(3):984-9.

130. Zhou H, Huang S. Role of mTOR signaling in tumor cell motility, invasion and metastasis. Curr Protein Pept Sci. 2011;12(1):30.

131. Martini M, De Santis MC, Braccini L, Gulluni F, Hirsch E. PI3K AKT signaling pathway and cancer: an updated review. Ann Med. 2014;46(6):372-83.

132. Lodewyks C, Rodriguez J, Yan J, Lerner B, Lipschitz J, Nfon C, Rempel JD, Uhanova J, Minuk GY. GABA-B receptor activation inhibits the in vitro migration of malignant hepatocytes. Can J Physiol Pharmacol. 2011;89(6): 393-400.

133. Nie H, Cao Q, Zhu L, Gong Y, Gu J, He Z. Acetylcholine acts on androgen receptor to promote the migration and invasion but inhibit the apoptosis of human hepatocarcinoma. PLoS One. 2013;8(4):e61678.

134. Hung C-S, Peng Y-J, Wei P-L, Lee C-H, Su H-Y, Ho Y-S, Lin S-Y, Wu C-H, Chang $Y-J$. The alpha9 nicotinic acetylcholine receptor is the key mediator in nicotine-enhanced cancer metastasis in breast cancer cells. J Exp Clin Med. 2011;3(6):283-92

135. Momi N, Ponnusamy MP, Kaur S, Rachagani S, Kunigal SS, Chellappan S, Ouellette MM, Batra SK. Nicotine/cigarette-smoke promotes metastasis of pancreatic cancer through a7nAchR-mediated MUC4 up-regulation. Oncogene. 2013;32(11):1384-95.

136. Lin G, Sun L, Wang R, Guo Y, Xie C. Overexpression of muscarinic receptor 3 promotes metastasis and predicts poor prognosis in non-small-cell lung cancer. J Thorac Oncol. 2014;9(2):170-8.

137. Xu R, Shang C, Zhao J, Han Y, Liu J, Chen K, Shi W. Activation of M3 muscarinic receptor by acetylcholine promotes non-small cell lung cancer cell proliferation and invasion via EGFR/PI3K/AKT pathway. Tumor Biol. 2015; 36(6):4091-100.

138. Belo A, Cheng K, Chahdi A, Shant J, Xie G, Khurana S, Raufman J-P. Muscarinic receptor agonists stimulate human colon cancer cell migration and invasion. Am J Physiol Gastrointest Liver Physiol. 2011;300(5):G749-60.

139. Xie G, Cheng K, Shant J, Raufman J-P. Acetylcholine-induced activation of M3 muscarinic receptors stimulates robust matrix metalloproteinase gene expression in human colon cancer cells. Am J Physiol Gastrointest Liver Physiol. 2009;296(4):G755-63.

140. Seckl MJ, Higgins T, Widmer F, Rozengurt E. [D-Arg1, D-Trp5, 7, 9, Leu11] substance P: a novel potent inhibitor of signal transduction and growth in vitro and in vivo in small cell lung cancer cells. Cancer Res. 1997; 57(1):51-4.

141. Guha S, Eibl G, Kisfalvi K, Fan RS, Burdick M, Reber H, Hines OJ, Strieter R, Rozengurt E. Broad-spectrum G protein-coupled receptor antagonist,[DArg1, D-Trp5, 7, 9, Leu11] SP: a dual inhibitor of growth and angiogenesis in pancreatic cancer. Cancer Res. 2005;65(7):2738-45.

142. Chen XY, Ru GQ, Ma YY, Xie J, Chen WY, Wang HJ, Wang SB, Li L, Jin KT, He $X \mathrm{~L}$, et al. High expression of substance $P$ and its receptor neurokinin-1 receptor in colorectal cancer is associated with tumor progression and prognosis. OncoTargets Ther. 2016;9:3595-602.

143. Lang K, Bastian P. Neurotransmitter effects on tumor cells and leukocytes. Prog Exp Tumor Res. 2007;39:99-121.
144. Entschladen F, Lang K, Drell TL, Joseph J, Zaenker KS. Neurotransmitters are regulators for the migration of tumor cells and leukocytes. Cancer Immunol Immunother. 2002:51(9):467-82.

145. Bigioni M, Benzo A, Irrissuto C, Maggi CA, Goso C. Role of NK-1 and NK-2 tachykinin receptor antagonism on the growth of human breast carcinoma cell line MDA-MB-231. Anti-Cancer Drugs. 2005;16(10):1083-9.

146. Li X, Ma G, Ma Q, Li W, Liu J, Han L, Duan W, Xu Q, Liu H, Wang Z. Neurotransmitter substance $P$ mediates pancreatic cancer perineural invasion via NK-1R in cancer cells. Mol Cancer Res. 2013;11(3):294-302.

147. Movafagh S, Hobson JP, Spiegel S, Kleinman HK, Zukowska Z. Neuropeptide $Y$ induces migration, proliferation, and tube formation of endothelial cells bimodally via Y1, Y2, and Y5 receptors. FASEB J. 2006;20(11):1924-6.

148. Medeiros PJ, Al-Khazraji BK, Novielli NM, Postovit LM, Chambers AF, Jackson DN. Neuropeptide $Y$ stimulates proliferation and migration in the $4 \mathrm{~T} 1$ breast cancer cell line. Int J Cancer. 2012;131(2):276-86.

149. Tilan JU, Krailo M, Barkauskas DA, Galli S, Mtaweh H, Long J, Wang H, Hawkins K, Lu C, Jeha D, et al. Systemic levels of neuropeptide $Y$ and dipeptidyl peptidase activity in patients with Ewing sarcoma-associations with tumor phenotype and survival. Cancer. 2015;121(5):697-707.

150. Hong SH, Tilan JU, Galli S, Izycka-Swieszewska E, Polk T, Horton M, Mahajan A, Christian D, Jenkins $S$, Acree $R$, et al. High neuropeptide $Y$ release associates with Ewing sarcoma bone dissemination - in vivo model of site-specific metastases. Oncotarget. 2015;6(9):7151-65.

151. Dupouy S, Viardot-Foucault V, Alifano M, Souazé F, Plu-Bureau G, Chaouat M, Lavaur A, Hugol D, Gespach C, Gompel A, et al. The Neurotensin Receptor-1 pathway contributes to human Ductal breast cancer progression. PLoS One. 2009;4(1):e4223.

152. Basbaum Al, Bautista DM, Scherrer G, Julius D. Cellular and molecular mechanisms of pain. Cell. 2009;139(2):267-84.

153. Ossipov $\mathrm{MH}$. The perception and endogenous modulation of pain. Scientifica. 2012;2012

154. Jimenez-Andrade JM, Bloom AP, Stake JI, Mantyh WG, Taylor RN, Freeman KT, Ghilardi JR, Kuskowski MA, Mantyh PW. Pathological sprouting of adult nociceptors in chronic prostate cancer-induced bone pain. J Neurosci. 2010; 30(44):14649-56.

155. Stock AM, Powe DG, Hahn SA, Troost G, Niggemann B, Zanker KS, Entschladen F. Norepinephrine inhibits the migratory activity of pancreatic cancer cells. Exp Cell Res. 2013;319

156. Palm D, Lang K, Niggemann B, Drell TL, Masur K, Zaenker KS, Entschladen F. The norepinephrine-driven metastasis development of PC-3 human prostate cancer cells in BALB/C nude mice is inhibited by beta-blockers. Int J Cancer. 2006;118

157. Barbieri A, Bimonte S, Palma G, Luciano A, Rea D, Giudice A, Scognamiglio G, La Mantia E, Franco R, Perdona S, et al. The stress hormone norepinephrine increases migration of prostate cancer cells in vitro and in vivo. Int J Oncol. 2015:47(2):527-34.

158. Azuma H, Inamoto T, Sakamoto T, Kiyama S, Ubai T, Shinohara Y, Maemura K, Tsuji M, Segawa N, Masuda H. $\gamma$-Aminobutyric acid as a promoting factor of cancer metastasis; induction of matrix metalloproteinase production is potentially its underlying mechanism. Cancer Res. 2003;63(23):8090-6.

159. Davis R, Rizwani W, Banerjee S, Kovacs M, Haura E, Coppola D, Chellappan S. Nicotine promotes tumor growth and metastasis in mouse models of lung cancer. PLoS One. 2009;4(10):e7524

160. Hao J, Shi F-D, Abdelwahab M, Shi SX, Simard A, Whiteaker P, Lukas R, Zhou Q. Nicotinic receptor $\beta 2$ determines NK cell-dependent metastasis in a murine model of metastatic lung cancer. PLoS One. 2013;8(2):e57495.

161. Esteban F, Muñoz M, González-Moles M, Rosso M. A role for substance $P$ in cancer promotion and progression: a mechanism to counteract intracellular death signals following oncogene activation or DNA damage. Cancer Metastasis Rev. 2006;25(1):137-45. 